JIKAP PGSD: Jurnal Ilmiah Ilmu Kependidikan

Vol,3. No,1. Tahun 2019

e-ISSN: 2597-4440 dan p-ISSN: 2597-4424

This work is licensed under a Creative Commons Attribution

4.0 International License

\title{
Mengurangi Kecenderungan Berperilaku Agresif Siswa Dengan Menerapkan Teknik Diskusi Dalam Bimbingan Kelompok Bagi Siswa Kelas XII IPA 1 Di SMA Negeri 1 Ulaweng
}

\author{
Hamsah \\ SMA Negeri 1 Ulaweng, Kab. Bone \\ Email: hamsah1965@gmail.com
}

\begin{abstract}
Abstrak: Penelitian ini menelaah Penerapan Teknik Diskusi Kelompok Dalam bimbingan Kelompok Untuk Mengurangi Kecenderungan Berperilaku Agresif Siswa kelas XII IPA 1 di SMA Negeri 1 Ulaweng. Masalah utama penelitian ini adalah: (1) Apakah penerapan teknik diskusi dalam bimbingan kelompok dapat mengurangi kecenderungan berperilaku agresif siswa kelas XII IPA 1 di SMA Negeri 1 Ulaweng? dan tujuan penelitian ini yaitu: (1) Untuk mengetahui apakah dengan menerapkan teknik diskusi dalam bimbingan kelompok dapat mengurangi kecenderungan berperilaku agresif siswa kelas XII IPA 1 di SMA Negeri 1 Ulaweng. Penelitian ini menggunakan jenis penelitian tindakan kelas dengan subjek sebanyak 20 orang yang merupakan siswa kelas XII IPA 1 di SMA Negeri 1 Ulaweng dengan fokus penelitian penerapan teknik diskusi untuk mengurangi kecenderungan berperilaku agresif siswa. Pengumpulan data menggunakan instrumen dokumentasi, angket, observasi dan jurnal. Analisis data menggunakan analisis persentase dan analisis statistik untuk uji validitas. Hasil penelitian menunjukkan bahwa: setelah diberi tindakan berupa penerapan teknik diskusi dalam bimbingan kelompok maka kecenderungan berperilaku agresif siswa kelas XII IPA 1 di SMA Negeri 1 Ulaweng berkurang.
\end{abstract}

Kata kunci: Berperilaku Agresif; Teknik Diskusi; Bimbingan Kelompok

\begin{abstract}
This study examines the Application of Group Discussion Techniques in Group Guidance to Reduce Aggressive Behavior in Students of Class XII Science 1 in Ulaweng 1 Public High School. The main problems of this study are: (1) Can the application of discussion techniques in group guidance reduce the tendency to behave aggressively in class XII IPA 1 students at Ulaweng 1 Public High School? and the purpose of this study are: (1) To find out whether applying the discussion technique in group guidance can reduce the tendency to aggressively behave in class XII IPA 1 students at Ulaweng 1 Public High School. This study uses a type of classroom action research with a subject of 20 people who are students of class XII IPA 1 at Ulaweng 1 Public High School with a focus of research on the application of discussion techniques to reduce the tendency of aggressive behavior of students. Data collection uses documentation instruments, questionnaires, observations and journals. Data analysis using percentage analysis and statistical analysis for validity tests. The results showed that: after being given an action in the form of the application of discussion techniques in group guidance, the tendency to behave aggressively in students of class XII IPA 1 in Ulaweng 1 Public High School decreased.
\end{abstract}

Keywords: Aggressive behavior; Discussion Techniques; Group conseling 


\section{PENDAHULUAN}

Remaja adalah sumber daya manusia yang perlu diberi dasar pendidikan sebagai generasi penerus bangsa dalam pembangunan nasional, untuk mewujudkan maksud tersebut maka perlu diterapkan pembinaan dan pendidikan pada remaja yang mutlak sebagai penerus cita-cita bangsa.

Pada realitasnya masih sering terjadi perilaku dikalangan remaja yang menimbulkan emosi. Kenakalan remaja khususnya dalam bentuk agresif cenderung meningkat baik dari segi kualitas maupun kuantitasnya. Banyak keluhan dari para orang tua, para pendidik (guru), dan masyarakat tentang munculnya perilaku remaja khususnya para pelajar yang cenderung mengganggu kepentingan umum (orang lain) atau merusak objek-objek tertentu. Perilaku dapat berbentuk perkelahian, tawuran, konvoi di jalan raya sehingga mengganggu lalu lintas, membolos, mengucapkan kata-kata yang tidak sopan, melanggar aturan dalam lingkungannya, merusak fasilitas belajar atau sekolah sampai pada tindakan menyakiti atau menyerang guru.

Myers

(Sarwono, 2002:

mengemukakan bahwa perilaku agresif adalah perilaku fisik atau lisan yang sengaja dengan maksud unutk menyakiti atau merugikan orang lain. Murray (Chaplin, 2004) mengatakan bahwa agresif adalah kebutuhan untuk menyerang, memperkosa atau melukai orang lain, untuk meremehkan, merugikan, mengganggu, membahayakan, merusak, menjahati, mengejek, mencemoohkan, atau menuduh secara jahat, menghukum berat, atau melakukan tindakan sadistis lainnya.

Menurut Ronen (Safaria: 2004) gangguan perilaku agresif merupakan gangguan umum yang terjadi pada anak-anak. Anak yang agresif mengalami kesulitan dalam kemampuan kognisi sosial, keterampilan sosial, dan penyesuaian diri. Untuk itu anak-anak yang agresif perlu diajarkan bagaimana mampu melihat peran dan sudut pandang orang lain, dan memahami pikiran dan perasaan orang lain, sehingga mereka perlu diberi latihan menumbuhkan keterampilan sosial, latihan sikap asertif dan mengontrol amarah.

Kecenderungan berperilaku agresif yang dialami oleh siswa dapat diatasi melalui pelaksanaan salah satu tekink layanan bimbingan yaitu bimbingan kelompok. Menurut Wingkel \& Hastuti (2004) bahwa bimbingan kelompok di institusi pendidikan menengah bermanfaat bagi guru pembimbing dan bagi siswa, yaitu bagi tenaga pembimbing mendapat kesempatan untuk berinteraksi secara langsung dengan banyak siswa sekaligus. Bagi para siswa kegunaannya ialah menjadi lebih sadar akan tantangan yang dihadapi, sehingga mereka memutuskan untuk berwawancara secara pribadi dengan konselor, lebih rela menerima dirinya sendiri setelah menyadari bahwa teman-temannya pun sering menghadapi berbagai masalah yang kerap kali sama,

Sukardi (2000) menyatakan bahwa bimbingan kelompok adalah salah satu layanan bimbingan dan konseling yang memungkinkan sejumlah peserta didik yang secara bersamasama memperoleh berbagai pengetahuan yang berfungsi menunjang kehidupan sehari-hari baik sebagai individu maupun sebagai pelajar melalui dinamika kelompok.

Sejalan dengan di atas, Nurihsan (2006) menyatakan bahwa bimbingan kelompok adalah bantuan terhadap individu yang dilaksanakan dalam situasi kelompok, bimbingan kelompok berupa penyampaian informasi atau aktivitas kelompok membahas masalah-masalah pendidikan, pekerjaan, pribadi dan sosial.

Jenis-jenis bimbingan kelompok terdiri atas dua yaitu: (1) bimbingan kelompok bebas, dimana dalam kegiatannya para anggota kelompok bebas mengemukakan pikiran dan perasaanya dalam kelompok dan selanjutnya apa yang disampaikan mereka dalam kelompok itulah yang menjadi pokok bahasan kelompok. (2) bimbingan kelompok tugas, salah satu bentuk penyelenggaraan bimbingan kelompok di mana arah dan isi kegiatan kelompok itu tidak ditentukan oleh anggotanya melainkan diarahkan kepada penyelesaian suatu tugas (Amti dan Marjohan: 1993)

Berdasarkan survei awal yang telah peneliti lakukan pada tanggal 3 Maret 2016 dengan mengadakan wawancara langsung dengan koordinator BK dan guru pembimbing di SMA Negeri 1 Ulaweng tentang kecenderungan berperilaku agresif yang dihadapi siswa kelas XII IPA 1. Dari hasil wawancara itu diperoleh informasi bahwa terdapat banyak siswa di kelas XII IPA 1 yang sering melakukan tindakan agresif baik dalam bentuk perkelahian dalam lingkup sekolah sendiri maupun antar sekolah, tawuran, konvoi di jalan, pelanggaran terhadap tata tertib sekolah, mengancam dan memaki teman bahkan tidak menutup kemungkinan ada 
siswa yang melakukan tindakan yang berusaha melawan guru dan orang tuanya. Selain itu fakta yang peneliti dapatkan di lapangan ada beberapa siswa yang berkeliaran di luar dan memilih berkumpul di warung-warung sekitar sekolah atau berkumpul di kios-kios tempat play station pada saat jam pelajaran berlangsung.

\section{METODE PENELITIAN}

Penelitian ini menggunakan pendekatan kualitatif dengan menggunakan penelitian tindakan kelas tentang penerapan bimbingan kelompok dalam mengurangi kecenderungan bersikap agresif siswa di kelas XII IPA 1 SMA Negeri 1 Ulaweng.

Prosedur penelitian tindakan kelas ini terdiri dari beberapa siklus, di mana tiap siklus dilaksanakan sesuai perubahan yang ingin dicapai. Sedangkan fokus dalam Penelitian ini, yaitu penerapan teknik diskusi dalam bimbingan Kelompok.

Untuk memperoleh batasan tentang kedua variabel penelitian dan pengukuran variabel tersebut, maka berikut ini dikemukakan definisi operasional variabel penelitian, sebagai berikut:

1. Penerapan teknik diskusi kelompok adalah usaha bersama untuk memecahkan suatu masalah, yang didasarkan pada sejumlah data, bahan-bahan, dan pengalamanpengalaman, di mana masalah ditinjau selengkap dan sedalam mungkin secara ideal.

2. Kecenderungan berperilaku agresif siswa adalah adanya keinginan untuk melakukan perilaku negatif, kekerasan guna menyakiti orang lain atau merusak suatu benda yang dilakukan secara fisik maupun verbal.

Subjek penelitian tindakan ini adalah siswa kelas XII IPA 1 SMA Negeri 1 Ulaweng sebanyak 20 orang.

Ada dua jenis instrumen yang digunakan dalam penelitian ini, yaitu stimulus material (bahan perlakuan) dan instrument pengumpulan data.

1. Stimulus Material (bahan perlakuan)

Bahan perlakuan berupa buku panduan sebagai bahan informasi dan tata cara pelaksanaan teknik diskusi dalam bimbingan kelompok untuk mengurangi kecenderungan berperilaku agresif siswa.

2. Instrumen Pengukuran

Untuk pengukuran variabel digunakan alat pengumpul data, yaitu:

a. Jurnal
Jurnal yaitu buku yang digunakan oleh pimpinan kelompok, peneliti dan siswa yang berisi tentang catatan segala kegiatan/kejadian yang terjadi pada saat kegiatan tindakan dilakukan. Untuk jurnal siswa lebih difokuskan bahan dari hasil diskusi.

b. Angket

Angket dalam penelitian ini yaitu daftar yang berisi pernyataan-pernyataan yang harus dijawab oleh siswa selaku anggota kelompok. Angket berupa pernyataan berkaitan dengan kecenderungan berperilaku agresif yang dialami oleh siswa dan menjadi bahan evaluasi tentang sejauh mana proses bimbingan kelompok dapat mengurangi kecenderungan berperilaku agresif siswa. Selain itu pada akhir pertemuan, siswa juga akan diberikan lembar respon yang berisi tanggapan siswa terhadap kegiatan yang telah dilakukan.

Pengumpulan data pada penelitian ini adalah sebagai berikut:

1. Analisis data

Analisa data adalah kegiatan menyeleksi, menyederhanakan, menfokuskan, mengabtraksikan, mengorganisasikan data secara sistematis dan rasional untuk memberikan bahan jawaban terhadap permasalahan penelitian.

Analisis data dilakukan melalui tiga tahap, yaitu: reduksi data, sajian data, dan penyimpulan. Pada tahap ini peneliti melakukan analisis data untuk melihat nilai validitas dari instrumen yang digunakan dengan menggunakan program SPSS 15,0 for windows, dari analisis data maka diperoleh standar nilai validitas angket adalah 0,444 , sehingga dari 45 item pernyataan terdapat 5 item yang tidak valid karena nilai $\mathrm{r}$ hitung yang diperoleh < (lebih kecil atau kurang dari 0,444 ) yaitu item nomor 3 $(0,277)$, item nomor $5(0,177)$, item nomor 9 $(0,001)$, item nomor $25(0,212)$, item nomor 36 $(0,048)$. Sehingga angket setelah uji validitas berubah menjadi 40 item pernyataan.(Lampiran halaman 91)

\section{HASIL DAN PEMBAHASAN}

Penelitian ini merupakan jenis penelitian tindakan kelas tentang penerapan teknik diskusi dalam bimbingan kelompok untuk mengurangi kecenderungan berperilaku agresif siswa yang dilaksanakan dalam 2 siklus, adapun rincian kegiatan dari hasil penelitian yang telah dilakukan sebagai berikut:

\section{Siklus I} I, yaitu:

Kegiatan yang dilaksanakan dalam siklus 
1. Perencanaan (planning)

Adapun kegiatan yang dilakukan dalam tahap perencanaan ini adalah sebagai berikut :

1) Membuat skenario perlakuan dengan menggunakan bimbingan kelompok melalui teknik diskusi.

2) Menentukan siapa yang akan menjadi pemimpin kelompok.

3) Menentukan waktu pelaksanaan tindakan. Berdasarkan kesepakatan dengan guru pembimbing di sekolah pelaksanaan siklus I akan dimulai pada tanggal 3 September 2016, pukul 09.00-10.00 WITA.

4) Menata setting untuk bimbingan kelompok

5) Membuat lembar observasi.

6) Menyediakan jurnal untuk mencatat hal-hal lain yang dianggap penting.

7) Mendesain angket yang digunakan sebagai alat evaluasi dan lembar respon untuk siswa selaku anggota kelompok.

2. Pelaksanaan tindakan

Kegiatan yang dilaksanakan dalam tahap ini adalah melaksanakan skenario tindakan, di mana pada siklus I ini terdiri atas tiga tahapan yang telah direncanakan sebagai berikut:

1) Tahap pertama

Pada tahap pertama ini strategi pembimbingan yang digunakan adalah curah pendapat, diskusi kelompok dan galery-walk.

2) Tahap kedua

Pada tahap ini strategi pembimbingan yang digunakan adalah curah pendapat dan diskusi kelompok adapun langkahnya sama dengan tahap pertama akan tetapi ada penmabahan dengan cara curah pendapat

3) Tahap ketiga

Pada tahap ini strategi pembimbingan yang digunakan adalah kerja mandiri dan diskusi kelompok.

3. Observasi (monitoring) I

Dalam pelaksanaan tindakan pada siklus I ini yang dilaksanakan dalam bentuk bimbingan kelompok melalui teknik diskusi, peneliti dibantu oleh seorang teman melakukan pengamatan tentang aktivitas yang dilakukan oleh siswa-siswa selaku anggota kelompok dan guru pembimbing selaku pemimpin kelompok selama mengikuti kegiatan bimbingan dengan mengecek lembar observasi yang telah disediakan berdasarkan nomor tempat duduk masing-masing siswa. Serta mencatat segala sesuatu yang dianggap penting yang terjadi selama pelaksanaan kegiatan berlangsung dalam jurnal yang telah disediakan. Dari hasil analisis lembar observasi pada siklus I, ternyata dari ketiga tahap yang telah dilakukan pada tahap 2 menunjukkan perubahan dibandingkan pada tahap 1 dan tahap 3 hal ini dapat dilihat pada partisipasi siswa untuk menjawab pertanyaan meningkat.

4. Analisa data dan refleksi ada beberapa hal yang menjadi bahan refleksi, antara lain:

1) Pada siklus pertama yang terdiri atas 3 tahap kegiatan di mana setiap tahap menggunakan teknik pembimbingan yang berbeda memang menyenangkan akan tetapi berdasarkan hasil observasi peneliti, teknik pembimbingan pertama yakni curah pendapat, diskusi kelompok dan galerywalk kurang efektif untuk digunakan karena membutuhkan waktu yang sangat lama dibandingkan dengan teknik yang lainnya, sementara dalam penelitian ini peneliti menggunakan waktu yang sangat terbatas akibatnya setiap kelompok belum selesai mengelilingi dan membaca hasil diskusi kelompok lain namun waktu sudah habis sehingga teknik ini lebih tepat digunakan dalam kegiatan yang lain dengan durasi waktu yang lebih banyak.

2) Bentuk kelompok yang dibagi kedalam beberapa kelompok kecil sudah sesuai dan membantu meningkatkan keaktifan siswa, akan tetapi berdasarkan pengamatan peneliti dan lembar respon yang telah diisi oleh siswa pelaksanaan diskusi dengan anggota kelompok yang tidak pernah berubah membuat siswa jadi bosan.

3) Dalam pelaksanaan kegiatan diskusi yang dilakukan, guru pembimbing selaku pemimpin kelompok terlalu aktif dalam menjawab pertanyaan ataupun tanggapan siswa. sehingga terkesan monopoli.

4) Dari beberapa penerapan teknik pembimbingan yang digunakan, peneliti mengamati siswa lebih tertarik dan lebih aktif mengikuti kegiatan bimbingan melalui teknik curah pendapat dan diskusi kelompok.

Adapun perbandingan hasil angket yang diberikan sebelum dan sesudah siklus I dapat dilihat pada tabel berikut: 
Tabel 4.1: Hasil analisis data angket tentang kecenderungan berperilaku agresif siswa dari pelaksanaan siklus I

\begin{tabular}{cccccc}
\hline Interval & f0 & Persentase & f1 & Persentase & Interpretasi \\
\hline $136-160$ & 8 & $40 \%$ & 6 & $30 \%$ & Menurun \\
\hline $112-135$ & 5 & $25 \%$ & 4 & $20 \%$ & Menurun \\
\hline $88-111$ & 4 & $20 \%$ & 6 & $30 \%$ & Meningkat \\
\hline $64-87$ & 2 & $10 \%$ & 3 & $15 \%$ & Meningkat \\
\hline $40-63$ & 1 & $5 \%$ & 1 & $5 \%$ & Tetap \\
\hline$\sum$ & 20 & $100 \%$ & 20 & $100 \%$ & \\
\hline
\end{tabular}

Berdasarkan hasil analisis angket diketahui bahwa terjadi perubahan setelah pelaksanaan siklus I. Untuk siswa yang mengalami kecenderungan berperilaku agresif kategori tinggi sebelum diberikan tindakan pada siklus I sebanyak 8 orang (40\%) setelah pelaksanaan siklus I berubah menjadi 6 orang (20\%) hal ini berarti terjadi perubahan, untuk siswa yang mengalami kecenderungan berperilaku agresif dengan kategori cukup tinggi sebelum pemberian tindakan pada siklus I sebanyak 5 orang $(25 \%)$ akan tetapi setelah pelaksanaan siklus I berubah menjadi 4 orang (20\%) terjadi perubahan yang menurun, untuk siswa yang mengalami kecenderungan berperilaku agresif dengan kategori sedang sebelum pelaksanaan tindakan pada siklus I sebanyak 4 orang $(20 \%)$ setelah pelaksanaan siklus I menjadi 6 orang (30\%) ini berarti terjadi perubahan yang meningkat, untuk siswa yang mengalami kecenderungan berperilaku agresif dengan kategori rendah sebelum pelaksanaan tindakan pada siklus I sebanyak 2 orang (10\%) namun setelah pelaksanaan siklus I menjadi 3 orang $(15 \%)$ terjadi peningkatan, sedangkan untuk kategori kecenderungan berperilaku agresif yang sangat rendah dimana sebelum pelaksanaan tindakan pada siklus I sebanyak 1 orang $(5 \%)$ dan setelah pelaksanaan siklus I masih tetap dan belum terjadi perubahan dengan jumlah siswa sebanyak 1 orang $(5 \%)$.

5. Perencanaan tindak lanjut/revisi I

Berdasarkan beberapa hasil refleksi pada siklus I, maka rencana tindak lanjut yang telah disepakati dan akan dilaksanakan pada siklus II sebagai berikut:

a. Pada siklus pertama yang menggunakan beberapa teknik pembimbingan akan direvisi dimana pada siklus kedua pelaksanaan tindakan akan menggunakan satu teknik saja yakni teknik curah pendapat dan diskusi.

b. Revisi kedua yang akan dilaksanakan adalah dengan menukar anggota kelompok. c. Tanggapan/pertanyaan yang diajukan oleh anggota kelompok lebih banyak dijawab oleh pemimpin kelompok akan revisi.

\section{Siklus II}

Kegiatan yang akan dilaksanakan dalam siklus II berdasarkan hasil refleksi dan revisi siklus I, yaitu:

\section{a. Perencanaan (planning) II}

Tahap perencanaan dilakukan sehari sebelum pelaksanaan kegiatan tindakan yakni tanggal 28 September 2016. Adapun kegiatan pada tahap persiapan yaitu:

1) Pada siklus II yang bertindak sebagai pemimpin kelompok.

2) Menentukan waktu untuk pelaksanaan kegiatan bahwa siklus II akan dilaksanakan pada hari Senin tanggal 29 September 2016 pukul 09.00-10.00 WITA

3) Tempat yang digunakan masih di tempat yang sama yakni ruang kelas

4) Dalam proses pengamatan aktivitas anggota dan pemimpin kelompok, peneliti masih menggunakan lembar observasi yang sama saat siklus I.

5) Bahan bacaan yang diberikan kepada siswa masih sama dengan bahan bacaan pada siklus I.

b. Pelaksanaan tindakan (acting) II

Adapun pelaksanaan tindakan dalam siklus II ini sesuai dengan revisi yang telah disepakati terbagi atas 3 tahapan dengan teknik pembimbingan yang sama yakni curah pendapat dan diskusi kelompok, adapun rangkaian kegiatannya sebagai berikut:

1) Tahap pertama

a) Kegiatan awal

(1) Dalam mengawali setiap pertemuan seperti biasa pemimpin kelompok kembali membangun.

(2) Pemimpin kelompok kembali menjelaskan aturan-aturan dan tujuan yang ingin dicapai dari kegiatan bimbingan tersebut.

(3) Sesuai hasil revisi, pemimpin kelompok mengarahkan kepada siswa untuk 
mengadakan perombakan anggota kelompok.

b) Kegiatan inti

(1) Pemimpin kelompok membagikan bahan bacaan (1) kepada setiap kelompok.

(2) Setiap kelompok secara bergantian diminta tampil di depan kelas untuk menyajikan hasil diskusinya.

(3) Pemimpin kelompok memberi kesempatan kepada setiap kelompok penanggap untuk menyampaikan saran

(4) Pemimpin kelompok meminta tanggapan balik kelompok penanggap

b) Penutup

Pemimpin kelompok menyimpulkan hasil diskusi siswa dan mereviuw kembali tujuan pertemuan. Selanjutnya menentukan jadwal pertemuan berikutnya.

2) Tahap kedua

Pada tahap kedua sama pelasksanaan dengan tahap pertama akan tetapi lebih dimanatapkan.

3) Tahap ketiga

Untuk tahap ketiga kegiatan bimbingan lebih dimantapkan lagi dengan menutupi kekurangan pada tahap1 dan 2 . c. Pengamatan (observing) II

Setelah pelaksanaan tindakan dalam siklus II selesai, peneliti dibantu oleh seorang temannya mengamati siswa dan mengecek hasil pengamatan tersebut kedalam lembar observasi yang telah disediakan.

d. Analisa data dan refleksi II

Seperti pada tahap sebelumnya setelah pelaksanaan tindakan dalam siklus II selesai, data-data dari hasil observasi, jurnal dan angket dikumpulkan dan dianalisis untuk selanjutnya diinterpretasikan, Berdasarkan hasil diskusi yang telah dilakukan dapat disimpulkan bahwa untuk pelaksanaan tindakan dalam siklus II dengan menggunakan teknik curah pendapat dan diskusi sangat menarik perhatian siswa.

Kegiatan selanjutnya, peneliti kembali menganalisis hasil angket yang telah diberikan kepada siswa setelah pelaksanaan siklus II kemudian membandingkan dengan hasil angket yang telah diberikan sebelumnya.

Adapun perbandingan hasil angket yang diberikan setelah siklus I dan setelah siklus II dapat dilihat pada tabel berikut:

Tabel 4.2 hasil analisis data angket kecenderungan berperilaku agresif siswa dari pelaksanaan siklus II

\begin{tabular}{cccccc}
\hline Interval & f1 & Persentase & f2 & Persentase & Interpretasi \\
\hline $136-160$ & 6 & $30 \%$ & 4 & $20 \%$ & Menurun \\
\hline $112-135$ & 4 & $20 \%$ & 2 & $10 \%$ & Menurun \\
\hline $88-111$ & 6 & $30 \%$ & 8 & $40 \%$ & Meningkat \\
\hline $64-87$ & 3 & $15 \%$ & 4 & $20 \%$ & Meningkat \\
\hline $40-63$ & 1 & $5 \%$ & 2 & $10 \%$ & Meningkat \\
\hline$\sum$ & 20 & $100 \%$ & 20 & $100 \%$ & \\
\hline
\end{tabular}

Dari hasil analisis angket pada siklus II dapat diketahui perubahan yang terjadi setelah pelaksanaan bimbingan melalui teknik diskusi dalam siklus II, yakni untuk siswa yang mengalami kecenderungan berperilaku agresif kategori tinggi sebelum diberikan tindakan pada siklus II sebanyak 6 orang $(30 \%)$ setelah pelaksanaan siklus II berubah menjadi 4 orang (20\%) hal ini berarti terjadi penurunan, untuk siswa yang mengalami kecenderungan berperilaku agresif dengan kategori cukup tinggi sebelum pemberian tindakan pada siklus II sebanyak 4 orang (20\%) akan tetapi setelah pelaksanaan siklus II terjadi penurunan menjadi 2 orang (10\%), untuk siswa yang mengalami kecenderungan berperilaku agresif dengan kategori sedang pada pelaksanaan tindakan dalam siklus I sebanyak 6 orang $(30 \%)$ setelah pelaksanaan siklus II menjadi 8 orang (40\%) ini berarti terjadi peningkatan, untuk siswa yang mengalami kecenderungan berperilaku agresif dengan kategori rendah pada siklus I sebanyak 3 orang $(15 \%)$ namun setelah pelaksanaan siklus II berubah menjadi 4 orang $(20 \%)$ terjadi peningkatan, sedangkan untuk kategori kecenderungan berperilaku agresif yang sangat rendah dimana pada siklus I sebanyak 1 orang (5\%) dan setelah pelaksanaan siklus II telah terjadi peningkatan dengan jumlah siswa sebanyak 2 orang (10\%). Dari hasil analisis angket, observasi dan jurnal, maka peneliti menarik kesimpulan tentang pelaksanaan siklus II yaitu telah terjadi perubahan dan dianggap bahwa untuk pelaksanaan teknik diskusi dalam bimbingan kelompok untuk mengurangi 
kecenderungan berperilaku agresif siswa dalam penelitian ini sudah cukup.

Berdasarkan pelaksanaan tindakan yang telah dilakukan oleh peneliti dalam penelitian melalui penerapan teknik diskusi dalam bimbingan kelompok untuk mengurangi kecenderungan berperilaku agresif yang terjadi pada siswa kelas XII IPA 1 SMA Negeri 1 Ulaweng telah menunjukkan perubahan terhadap kecenderungan berperilaku agresif siswa yang ditandai dengan adanya penurunan pada tingkat kecenderungan berperilaku agresif siswa melalui pengamatan langsung terhadap aktivitas keseharian siswa selama peneliti melakukan penelitian dimana dalam kesehariannya kebiasaan siswa yang sering menyerang secara fisik, saling memaki, menghina, dan mengejek sudah jarang ditemukan selain itu perubahan yang terjadi dapat pula dilihat pada hasil analisis angket yang telah peneliti paparkan sebelumnya.

Berdasarkan hasil penelitian dan pendapat di atas, tampak bahwa penerapan bimbingan kelompok dengan menggunakan teknik diskusi merupakan tindakan yang dapat dilakukan untuk membantu siswa dalam memecahkan masalah yang sedang dihadapi seperti yang telah peneliti lakukan, sehingga dapat meminimalisasi kecenderungan berperilaku agresif yang dihadapi oleh siswa. Meskipun dalam pelaksanaan penelitian ini terdapat kekurangan, seperti bahan bacaan sebagai bahan informasi untuk siswa yang diberikan oleh pimpinan kelompok semestinya direvisi setiap selesai pelaksanaan satu siklus, waktu yang dibutuhkan dalam penelitian ini sangat terbatas, sebagian siswa masih kurang menyadari akan pentingnya memahami bahan informasi yang diberikan untuk mengurangi kecenderungan berperilaku agresif yang pada akhirnya akan merugikan diri sendiri dan orang lain.

\section{SIMPULAN DAN SARAN}

Berdasarkan hasil penelitian tindakan yang telah dilakukan peneliti di kelas XII IPA 1 SMA Negeri 1 Ulaweng, maka dapat disimpulkan bahwa penerapan teknik diskusi dalam bimbingan kelompok merupakan salah satu teknik yang dapat diterapkan untuk mengurangi kecenderungan berperilaku agresif siswa. Teknik yang diterapkan oleh peneliti dapat melatih siswa dalam mendiskusikan dan menyelesaikan masalah yang sedang dihadapinya, selain itu teknik ini tidak pernah ditemukan oleh siswa sebelumnya sehingga lebih tertarik dalam mengikuti kegiatan bimbingan. .

Sehubungan dengan kesimpulan di atas, maka diajukan saran sebagai berikut :

1. Sebaiknya pihak sekolah menyediakan waktu yang cukup agar pelaksanaan kegiatan teknik diskusi dapat lebih efektif.

2. Guru pembimbing sebaiknya melakukan kegiatan ini lebih intensif sehingga dapat mengurangi dan mengantisipasi terjadinya kecenderungan berperilaku agresif yang dihadapi oleh siswa.

3. Siswa, hendaknya berusaha secara optimal memanfaatkan layanan bimbingan dan konseling khususnya layanan bimbingan kelompok agar dapat memperoleh berbagai informasi.

\section{DAFTAR RUJUKAN}

Abimanyu, S \& samad, S. 2003. Pedoman Penulisan Skripsi. Makassar: FIP UNM

Abimanyu, S. 1983. Teknik Pemahaman Individu (Teknik Non Testing). Makassar: FIP UNM.

Amti, Erman \& Marjohan. 1993. Bimbingan dan Konseling. Jakarta. Departemen Pendidikan dan Kebudayaan Direktoral Jenderal Pendidikan Tinggi Proyek Pembinaan Tenaga Kependidikan.

Bulatau. J. 1971. Teknik Diskusi Berkelompok. Yogyakarta: Kanisius

Chaplin. 2004. Kamus Lengkap Psikologi. Jakarta: PT Raja Grafindo Persada

Djamarah. Syaiful. 2005. Guru dan Anak Didik Dalam Interaksi Edukasi Suatu Pendekatan Teoritis Psikologis. Jakarta: Rineka Cipta

Djumhur \& Surya, Moh. 1999. Bimbingan dan Konseling Di Sekolah. Bandung: CV. Ilmu.

Hallen, A. 2005. Bimbingan dan Konseling. Ciputat : PT. Ciputat Press.

Kartono, K. 2000. Patologi Sosial (Kenalan Remaja). Jakarat: PT Raja Grafindo Persada

Kisni, T. D. \& Hudaniyah. 2001. Psikologi Sosial. Jilid 1 Universitas Muhammadiyah Malang Press

Koeswara, E. 1988. Agresi Manusia. Bandung: PT. Eresco

Kunandar. 2008. Langkah Mudah Penelitian Tindakan Kelas Sebagai Pengembangan Profesi Guru. Jakarta: PT Grafindo Persada 
JIKAP PGSD: Jurnal Ilmiah Ilmu Kependidikan

Mahmud, Alimuddin. 2005. Penerapan Konseling Gender Untuk Menigkatkan Rasa Keberhasilan Dalam Karier (Carier Self-Effiicacy) Siswa: Studi PraEksprimental di SMA Negeri 9 Makassar. Disertasi. Universitas Negeri Malang.

Malik, Muh. Anas. 2007. Pengantar Psikologi Sosial. Makassar: Badan Penerbit UNM

Mufakhir, Abdul. 2007. Pengaruh Sikap Menghadapi Konflik Antara Kelompok Mahasiswa Terhadap Kecenderungan Perilaku Agresif (Studi Pada Fakultas Teknik UNM). Tidak diterbitkan. Makasar: Fakultas Psikologi UNM

Mutaddin. 2002. Faktor-faktor penyebab perilaku agresif. (http:/www. Scribd dot/12007911/) diakses 7 Juni 2009.

Nurihsan, Achmad Juntika. 2006. Bimbingan dan Konseling dalam Berbagai Latar Kehidupan. Bandung : PT. Refika Aditama.

Pandang, A. 2007. Model Bimbingan Karier Responsif Gender. Makassar: FIP UNM

Prayitno \& Amti, Erman. 2002. Dasar-dasar Bimbingan dan Konseling. Jakarta: PT. Rineka Cipta.

Prayitno. 1995. Layanan Bimbingan dan Konseling Kelompok (Dasar dan Profil). Jakarta : Ghalia Indonesia.

Romlah, T. 1989. Teori dan Praktek Bimbingan Kelompok. Jakarta: Departemen Pendidikan dan Kebudayaan Direktorat Jendral Pendidikan Tinggi.

Safaria, Triantoro. 2004. Terapi Kognitif Perilaku Agresif Untuk Anak. Yogyakarta: Graha Ilmu.

Sarwono, S. W. 2002. Psikologi Sosial. Jakarta: Balai Pustaka.

Sukardi, Dewa ketut. 2000. Pengantar Pelaksanaan Program Bimbingan dan Konseling Di Sekolah. Jakarta. Penerbit : Rineka Cipta.

Tim Pelatih Proyek PGSM. 1999. Penelitian Tindakan Kelas (Classroom Action Research). Bahan Pelatihan Dosen LPTK dan Guru Sekolah Menengah. Departemen Pendidikan dan Kebudayaan Dirjen Dikti Proyek PGSM IBRD LOAN No. 3979IND.

Wingkel \& Hastuti, Sri. 2004. Bimbingan dan Konseling Di Institusi Pendidikan. Yogyakarta : Media Abadi.
Zamzami, A. 2007. Agresivitas Siswa SMK DKI Jakarta. Jurnal Pendidikan Dan Kebudayaan, tahun ke-13,No. 069. 